\title{
Investigating the Foundation of Child Development Policies: A Case Study in Sumbawa Regency, Indonesia
}

\author{
Fahrunnisa Fahrunnisa \\ Faculty of Communication \\ Universitas Teknologi Sumbawa
}

\author{
Apriadi Apriadi* \\ Faculty of Communication \\ Universitas Teknologi Sumbawa \\ apriadi.lanandrang@uts.ac.id
}

\author{
Ayuning Atmasari \\ Faculty of Pshycology \\ Universitas Teknologi Sumbawa
}

\author{
Ofi Hidayat \\ Faculty of Communication \\ Universitas Teknologi Sumbawa
}

\author{
Abbyzar Aggasi \\ Faculty of Communication \\ Universitas Teknologi Sumbawa
}

\begin{abstract}
Protecting children, women and marginal groups is one of the national development priorities and in compliance with the Sustainable Development Goals (SDGs) on the pillars of social development. Through Presidential Decree No.57 of 2017 concerning Implementation of SDGs Achievement, each region synergizes SDGs with the Regional Medium-Term Development Plan (RPJMD). In West Nusa Tenggara Province, one of the synergies lies in the goal of gender equality, namely increasing the role of women in regional development and fulfilling children's rights. Sumbawa District is one of the districts in West Nusa Tenggara that has a synergy of SDGs with RPJMD related to institutional strengthening and fulfillment of children's rights. This study aimed at identifying child development policies and analyzed constraints in the implementation of child development policies in Sumbawa district. This research used a community development approach, based on justice rights and was a participatory action research involved Regional Departments/service agencies that have duties and functions in fulfilling children's rights. The result of this action research was that the implementation of the development and fulfillment of children's rights could not be fully carried out by the government due to insufficient institutional capacity because of weak coordination among Regional Departments (OPDs).
\end{abstract}

Keywords - Child development, Child rights, Sumbawa Regency, SDGs.

\section{INTRODUCTION}

The protection of children, women and marginalized people is one of the goals of sustainable development (SDGs), which is contained in the pillars of social development. In the Indonesian context, the Acceleration of the Implementation of SDGs is mandated in Government Regulation No. 57 of 2017 which is supported by the Regional Medium-Term Development Plan (RPJMD). One specific effort in realizing sustainable development is through the policy of fulfilling children's rights. Fulfillment of children's rights is an important agenda considering that around 83 million (32.24\%) of Indonesia's 258 million population are children (KPPPA, 2017). On the other hand, children are the heirs of the future of the nation, therefore, various efforts have been made by the government, community and private sector in order to develop and improve the conditions and situations of Indonesian children. However, this has not been as expected because the development of children carried out so far is still partial and sectoral, far from ideal children development which is holistic, integrative, and sustainable [1].

The fulfillment of children's rights is a shared ideal of the countries of the world as set out in the Convention on The Rights of the Child. The Convention on the Rights of the Child (CRC) affirms that every country must be highly committed to protecting children. The convention authorized by the UN on November 20, 1989 has the power to force countries to commit and guarantee the fulfillment of children's rights and child protection. Therefore, the Government of Indonesia has ratified the Convention on the Rights of the Child through Presidential Decree Number 36 of 1990. This requires that the fulfillment of children's rights be a continuing and sustainable effort [2].

In order to accelerate the implementation of the CRC, the government through the Ministry of Women's Empowerment and Child Protection (KP3A) of the Republic of Indonesia issued Ministerial Regulation No. 11 of 2011 concerning the Policy for the Development of Regencies/Cities that are ChildFriendly (KLA). Through this policy, the government seeks to realize a child-friendly country. KLA aims to develop district/city government initiatives that lead to efforts to transform the concept of children's rights into policies, programs and activities to ensure the fulfillment of children's rights in the regency/city. Children's rights include: a) civil rights and freedoms; b) family environment and alternative care; c) basic health and well-being; d) education, leisure time utilization, and cultural activities; e) special protection. This policy is implemented in the principles of good governance; transparency, accountability, participation, information disclosure, and rule of law; non-discrimination; the best interests of the child; the right to life, the right of the child to survival and development; and respect for children's views.

Implementation of the KLA policy has been carried out by several Regencies/Cities in Indonesia. Based on data from the Ministry of Women's Empowerment and Child Protection (KP3A) for 2017, 349 out of 516 Regencies/Cities in Indonesia have initiated the Formation of Child-Friendly Regencies/Cities [3]. While the Regencies/Cities that have started the construction and development of child-friendly areas accounted for 68 percent. West Nusa Tenggara (NTB) is one of the provinces that has initiated the development of KLA 
since 2015. The development of KLA in NTB has only been carried out by 5 of 10 regencies/cities, including Mataram City, Bima City, Bima Regency, Dompu Regency and North Lombok Regency. In 2017, an there was an increase in one district in the province which began to initiate the development of KLA, namely the Sumbawa Regency. Sumbawa Regency's commitment to develop the KLA is contained in the 2016-2021 Regional Mid-Term Development Plan.

The implementation of the KLA development policy in Sumbawa Regency is very important considering the NTB Province Child Protection Institute (LPA) noted that in 2016 and 2017, child violence in NTB Province experienced a fairly high increase. In 2016, LPA handled 24 cases of child violence. Meanwhile, in 2017 the cases handled by LPA reached 38 cases of child abuse, including 32 cases of sexual violence and 6 cases of physical violence. Of the seven cities/regencies in NTB Province, Sumbawa Regency is the area with the highest number of sexual violence cases, reaching 13 sexual violence cases [4].

In an effort to support the implementation of ChildFriendly Regency (KLA), the local government established the Sumbawa Regency Local Regulation (Perda) No. 7 of 2017 concerning Implementation of Child Protection. In addition, a Task Force has been formed to accelerate the implementation of the KLA in Sumbawa Regency. Based on these conditions, this study was directed at analyzing the implementation of child development policies in Sumbawa Regency.

\section{RESEARCH METHODOLOGY}

This study employed a community development approach with a participatory action research method. This is a research method that involves relevant stakeholders actively assessing ongoing actions [5]. According to Laksono et al [6], participatory action research begins with a problem, then observations are made to observe the situation and followed by data collection then synthesize the information and data. The focus of this research was on the identification and analysis of the Sumbawa district government policy related to the fulfillment of children's rights and child development as well as an analysis of the constraints and challenges in implementing the policy.

This research was conducted in the Sumbawa regency government by involving agencies/offices that have concerns in child development and fulfillment of children's rights in Sumbawa regency. Those agencies were the Social Service, the Office of Population Control, Family Planning, Women Empowerment and Child Protection, the Education Office, the Health Office, Regional Development Planning Agency at Sub-National Level and the Women's and Children's Services Unit of the Sumbawa district police station. This research was conducted from 2018 to 2019. There were two types of data gathered in this research, primary data and secondary data. The primary data were gathered through participation observation, in-depth interviews and Focus Group Discussion. Meanwhile, secondary data were obtained through desk study by collecting the results of previous studies.

\section{RESULTS AND DISCUSSIONS}

\section{A. Child Development Policy in Fulfilling Children's Rights and Protection in Sumbawa Regency}

Improving the quality of human resources becomes an important factor in regional development. According to Damarsari et al [7], the success of comprehensive regional development is influenced by the quality of human resources, because the higher the quality of human resources in an area, the higher the regional income. In regard to preparing the Regional Medium-Term Development Plan (RPJMD) of Sumbawa Regency for 2016-2021, increasing human resources becomes one of the strategic issues in the framework of regional development, especially in terms of improving the quality of education and health. This is because education and health are fundamental and have a significant impact on the sustainable development of the Sumbawa regency.

Besides improving the quality of education and health, the other objectives set in the RPJMD are also related to improving the quality of human resources in order to improve the effectiveness of child protection. Child protection is one of the children's rights that must be fulfilled, besides the right to survive, the right to growth and development and the right to participate [2]. Furthermore, the targets to be achieved from increasing the effectiveness of child protection are the realization of child-friendly regency institutions, the achievement of child rights clusters, the realization of child rights information and adequate child protection assistance as well as the even distribution of P2TP2A (Center for Integrated Services for Empowering Women and Children) in each district.

The realization of RPJMD of Sumbawa Regency shows that the local government has a commitment and willingness to build and maximize regional leadership in accelerating the fulfillment of children's rights and child development. In addition, legal products that promote and protect children's rights in Sumbawa regency had already been existed, such as Local Governement Regulation (Perda) No. 7 of 2016 concerning Non-Smoking Areas (KTR), in which this regulation aimed at ensuring children to get their right not to be exposed to cigarette smoke in public spaces and get a good and healthy living environment. According to [2] the nonsmoking area policy is a form of protection provided by the local government to the public against the effects of cigarettes and smoke from burning cigarettes. The Regional Regulation on Non-Smoking Areas regulated the application of NonSmoking Areas in Health Service Facilities, Places of Worship, Places for Teaching and Learning, Children Playgrounds, Public Transport and Public Places, and also smoking areas.

Another legal product that also supports the protection and fulfillment of children's rights and child development is Local Government Regulation No. 7 of 2017 concerning the Implementation of Child Protection. The regulation contains the prevention and handling of child protection for victims of violence, children in disaster emergency situations, neglected children, children in conflict with the law, and children who live and work on the street. In addition, this regulation also regulates the Child-Friendly Regency Task Force. The main tasks of the Task Force are to disseminate information, advocate and communicate information and educate on childfriendly regency policies, and collect basic data and prepare 
Regional Action Plans for Child-Friendly Regency. Furthermore, in 2019 the local government also stipulated Regents Regulation Number 47 of 2019 concerning the Integrative Holistic Early Childhood Development of Sumbawa Regency. This regulation was set with the aim of meeting the basic needs of early childhood so that children can grow and develop optimally, as well as the implementation of integrated early childhood services and protecting children from all forms of violence and neglect.

Meanwhile, in enhancing the effectiveness of providing child protection and conducting socialization related to laws and regulations relating to the protection and fulfillment of children's rights and child development, the Local Government established a Child-Friendly Regency Task Force through Regent Decree Number 1372 of 2017. The existence of this task force was expected to be the agency that coordinates policy efforts, programs and activities to realize the Sumbawa regency which is child-friendly. According to [8], the task force is a non-sectoral organizing network consisting of 4 components, namely bureaucrats, entrepreneurs, civil society and civil society organizations and academics. In addition, the institution that focuses on providing services for the protection of children from acts of violence is P2TP2A (Center for Integrated Services for Empowering Women and Children), whose position is under the agency of women's empowerment and child protection in Sumbawa Regency.

In bridging the communication and aspirations of children with local governments, as well as fulfilling the right of children's participation in promoting activities that involve children in programs that will influence them, listen to their opinions and consider them in the decision making process, then in 2017 a forum for children was formed at regency level, named FAS (Forum Anak Samawa/Samawa Children's Forum) through Regent Decree No. 952 of 2017. This forum is important in order to provide an understanding of how children obtain four basic rights, namely the right to life, growth and development rights, protection rights and participation rights.

\section{B. Implementation of Child Development Policies in Fulfilling Children's Rights and Protection in Sumbawa Regency}

Sumbawa Regency Government had declared its region as a Child-Friendly Regency. This program had been formulated in the Regent's Regulation Number 19 Year 2019 concerning the Regional Action Plan for Child-Friendly Regency in Sumbawa Regency in 2018-2022. According to Harya (2018), the purpose of this Action Plan is as a guide or direction in preparing policies, programs and activities from the planning, implementation and monitoring and evaluation stages. However, the implementation of the program had not been running optimally. Based on the performance report of the 2019 regional agencies, the achievement of the fulfillment of Child-Friendly Regency indicators has not yet been fulfilled in general. They are related to civil rights and freedoms, especially in the fulfillment of Child-Friendly Information (ILA). In the education cluster, relating to realizing childfriendly schools, this program still had not been running well and the facilities for child-friendly cultural and creative activities had also not been able to be fulfilled.
Meanwhile, several programs that had been carried out mainly by the P2KBP3A (the Office of Population Control, Family Planning, Women Empowerment and Child Protection), namely forming the Sumbawa Children Forum in 2017 and had carried out the 2018 Sumbawa Children's Ambassador Election which was participated by high school students [9]. This activity is expected to be a trigger for children to become the best ambassadors for the young generation. Children's forums are a media and a forum to fulfill children's participation rights which are specifically emphasized in article 10 of Law Number 23 of 2002 concerning Child Protection [10]. However, the existence of the Samawa Children's Forum (FAS) has not been able to bridge and accommodate the aspirations of children in the Sumbawa Regency as a whole and has not been able to realize the children's forum in each district optimally. Furthermore, the P2KBP3A Office also developed a Community-Based Integrated Child Protection (PATBM) program. This program was socialized in five districts; Sumbawa, Labuhan Badas, Unter Iwes, Batu Lanteh, and Moyo Hilir. This program aimed at making the community able to recognize, analyze and take the initiative to prevent and resolve the problem of violence against children in their work area. However, the socialization and implementation of PATBM has not run optimally, one of the factors is due to the low quality of human resources and there are limited human resources who understand the Convention on the Rights of the Child properly.

Meanwhile, several programs that had also been carried out by the P2KBP3A (the Office of Population Control, Family Planning, Women Empowerment and Child Protection) were training to assist victims of violence towards women and children as well as socialization of marriageable age. This program aimed at socializing the ideal age of marriage so that early marriage actors can understand the minimum age of marriage. However, this activity did not run in a sustainable way so that it had less overall impact on the community. In addition, the construction of 10 parks in several regions of Sumbawa Regency as an effort to create a ChildFriendly Regency (KLA) would be built in 2020 by the local government and complete several supporting facilities such as free Wifi access as a means of supporting the realization of controlling internet abuse on adolescents [11]

Programs that had been carried out by several agencies that have concerns in fulfilling children's rights were still in the form of socialization and understanding of concepts so that they had not had a significant and equitable impact in the Sumbawa Region. Monitoring and evaluation had not yet run optimally from every program. This was also shown in the Government Agencies Performance Report (LKIP) of the Family Planning Population Control Agency for Women's Empowerment and Child Protection in 2019, that some of the clusters determined as the basis for forming a Child-Friendly Regency/City were still not fully met.

\section{Obstacles and Challenges Encountered by Sumbawa Regency Government in Fulfilling Children's Rights and Protection}

The initiative to establish Sumbawa as a Child-Friendly Regency is a strategic step taken by the local government to provide space for participation, protection and fulfillment of children's rights. In implementing the Child-Friendly Regency policy, there are a number of basic principles that must be fulfilled; good governance and accountability, non- 
discrimination, the best interests of children, and respect for children's views. Sumbawa Regency can be categorized as Child-Friendly Regency if it has fulfilled children's rights as measured by the Child-Friendly Regency indicator, namely institutional strengthening and fulfillment of children's rights through 5 clusters.

Institutional strengthening in the development of ChildFriendly Regency concept includes: (a) the availability of regional regulations/policies on Child-Friendly Regency and budget allocations for policy implementation; (b) the establishment of a Child-Friendly Regency Task Force by involving a children's forum, (c) the formation of a ChildFriendly District (KELANA) and Child-Friendly Village (DEKELA); (d) the availability of child's profile; (e) the formation of a Regional Action Plan; and (f) involvement of social institutions, the business community and mass media. Although the institutional strengthening of the Child-Friendly Regency in Sumbawa Regency had just been started in 2017, which was initiated by the Office of Population Control, Family Planning, Women Empowerment and Child Protection, it does not merely make the Sumbawa Regency deserve to be called a Child-Friendly Regency. This is due to the fact that there were still a number of things that had yet to be fulfilled as indicators of Child-Friendly Regency, such as the Representative of the Regional Apparatus Organization (OPD) incorporated in the Child-Friendly Regency Task Force. This force had not fully understood their functions and responsibilities, so that effective coordination and communication had not yet been established internally and externally. This is proved by the absence of achievements in the form of program planning and activities from the ChildFriendly Regency Task Force. On the other hand, the presence of the Regional Apparatus Organization (OPD) representatives in the Child-Friendly Regency Task Force had not been able to identify programs related to children to be collaborated so that they could support one another. In fact, the cross-Regional Apparatus Organization (OPD) work program was expected to be part of the implementation of the Child-Friendly Regency. Unfortunately, it had not been fully synchronized. As part of the institutional strengthening of the Child-Friendly Regency in Sumbawa Regency, the P2KBP3A (the Office of Population Control, Family Planning, Women Empowerment and Child Protection) also initiated the issuance of Regional Regulation No. 7 of 2017 concerning the Implementation of Child Protection which was considered part of the Child-Friendly Regency.

Fulfillment of children's rights is one indicator that must be fulfilled by the regency/city in order to become a ChildFriendly Regency/City. In fulfilling children's rights, there are five child rights clusters that must be fulfilled by Sumbawa Regency to realize the Child-Friendly Sumbawa Regency. However, the five clusters had not been implemented well so that it made it an obstacle and challenge for the Local Government to fulfill children's rights. The obstacles were:

\section{Civil Rights and Freedoms}

Inability to reach of the national target $(78.25 \%)$ related to the percentage of children who had received Birth Certificates in 2017 was due to the unavailability of policies on accelerating the implementation of birth registration and the distribution of Birth Certificate. Distibution of Child Identity Cards (KIA) also had not become a focus of local governments, so there was no data on children receiving the cards. On the other hand, Child Identity Cards data is a database of children's profiles in Sumbawa Regency. Local governments had not yet had policies or regulations related to Child-Friendly Information (ILA) services, so that the vacant policy resulted in children not being able to access all information according to their age.

\section{Family Environment and Alternative Care}

Alternative care institutions for children with disabilities and the unavailability of data on children with disabilities and children with disabilities adopted were still unavalaible in Sumbawa Regency. Furthermore, the regency had not yet had a policy on Child Friendly Playrooms (RBRA). Data on schools that had RASS (Safe Routes to/from Schools) as well as pedestrian and crossing facilities around schools accessible to persons with disabilities Sumbawa Regency were not yet avalaible.

\section{Basic Health and Well-being}

The infant mortality rate was still relatively high. In 2017 , there were 54 deaths of infants and the percentage of children under five with malnutrition reached $5.49 \%$. The percentage of stunting data is also still in contrast with the national data. Based on 2017 national data, stunting cases in Sumbawa Regency are $20 \%$ higher than the national figures. The stunting rate from the Sumbawa Regency Health Office is $11.53 \%$. The difference in data was because the measurement tools used by the Sumbawa Regency Health Office did not meet the standards used at the national level.

\section{Education, Utilization of Leisure Time, and Cultural Activities}

Policies to encourage the realization of Child Friendly Schools (SRA) in Sumbawa district were not yet available. Moreover, local governments did not yet have data on numbers and percentages of elementary and junior high schools that had become Child-Friendly Schools. The Sumbawa regency government did not yet have regulations on culture, creativity and recreation for children. Moreover, the Children's Creativity Center (PKA) facilities were only available in the arts building in Kerato Village that was not accessible to people with disabilities.

\section{Special Protection}

The unavailability of a referral mechanism, monitoring and reporting of child victims of violence and neglect, the unavailability of psychologists and psychiatrists, and trained Human Resources on Conventions of the Rights of the Child (CRC) became problems for Sumbawa Regency. Policies on child labor and budget allocations were also not yet available. This condition was also worsened by the unavailability of agency data for the recruitment of child labor, prevention SOPs, mechanisms for monitoring child labor, recording and reporting of child labor, and no data on children involved in WFCL (Worst Forms of Child Labor). In a disaster emergency situation, the local government did not yet have an early warning system for the disaster that can be understood by children, and the absence of child-friendly evacuation routes. Moreover, there was no mechanism for recording and reporting of children with disabilities. Besides, Sumbawa Regency did not yet have regulations regarding child victims of terrorism networks or stigmatization and prevention efforts. 


\section{CONCLUSIONS}

Sumbawa Regency is one of the five regencies in West Nusa Tenggara Province that has not yet reached a childfriendly regency status in 2019. One of the factors that might become the obstacle was the existence of sectoral egos and weak coordination between relevant Agencies and having interests in child development including fulfilling children's rights and child protection in Sumbawa district. The commitment and willingness of the local government in realizing the fulfillment of children's rights and child protection could be seen from the 2016-2021 Regional Medium-Term Development Plan (RPJMD) and legal products that had been ratified as a policy in child development. However, the implementation stage was still not optimal and there were still many Child-Friendly Regency/City indicators that could not be reached in 2019. Among them was the high rate of child violence, especially physical and sexual violence in the last three years. Unfulfilled child-friendly information facilities (ILA), unfulfilled infrastructure facilities in child-friendly public spaces, especially children's playgrounds, the realization of childfriendly schools and the unfulfillment of child protection against laws resolved through diversion.

This research was carried out well because of the collaboration with the Samawa Center (Research and Empowerment) and the Sumbawa Regency Development Planning Agency at Sub-National Level (Bappeda).

\section{REFERENCES}

[1] Fahrunnisa and Apriadi, "Kesiapan Kabupaten Sumbawa Menjadi Kabupaten Layak Anak (Ditinjau dari aspek penguatan kelembagaan dan implementasi Pemenjuhan Hak Anak)," J. Tambora, vol. 3, no. 3, 2019.

[2] A. Apriadi and T. D. Cahyono, "Perlindungan Anak Korban Tindakan Kekerasan," Soc. J. Ilmu Adm. dan Sos., vol. 8, no. 2, pp. 65-81, 2019.

[3] "126 raih penghargaan kota layak anak," Jawapos, 2017.

[4] "Sebulan Empat Kasus Kekerasan Anak Terjadi di Sumbawa," Globalfm, 2017.

[5] A. Affandy, Modul Participatory Action Research; Untuk Pengorganisasian Masyarakat. Surabaya: LPPM UIN Sunan Ampel, 2014.

[6] A. D. Laksono, H. Megatsari, and M. Yoto, "Riset Aksi Partisipatif Desa Sehat Berdaya," 2019.

[7] R. Damarsari, Junaidi, and Yulmardi, "Kinerja Pembangunan Daerah Kota/Kabupaten di Provinsi Jambi," J. Perspekt. Pembiayaan dan Pembang. Drh., vol. 2, no. 3, 2015.

[8] P. Wirutomo, D. I. Yasmine, R. J. Surayadu, and H. Suandi, Modul Pelatihan Fasilitator Pembentukan Gugus Tugas Revolusi Mental. Jakarta: Kementerian Koordinator Bidang Pembangunan Manusia dan Kebudayaan, 2016.

[9] "SMAN 2 Sumbawa Dominasi Duta Anak Samawa 2018," Kabarsumbawa.com, Sumbawa, 15-May-2018.

[10] D. A. Rizki, S. Sulastri, and M. Irfan, "Pemenuhan Hak Partisipasi Anak Melalui Forum Anak dalam Implementasi Kebijakan Kota Layak Anak di Kota Bandung," Share Soc. Work J., vol. 5, no. 1, 2015.

[11] "Forum Anak Samawa Wadah Pemenuhan Hak Partisipasi Anak," infopublik.id, Sumbawa, 2018. 